\title{
New Nomenclatural Combinations in the Phototrophic Sulfur Bacteria
}

\author{
NORBERT PFENNIG and HANS G. TRÜPER
}

Institut für Mikrobiologie der GSF, 34 Göttingen, Germany

\begin{abstract}
The following new combinations for names of species of phototrophic sulfur bacteria are proposed: (i) Thiocystis gelatinosa (Winogradsky) comb. nov., (ii) Thiodictyon bacillosum (Winogradsky) comb. nov., (iii) Amoebobacter pendens (Molisch) comb. nov., (iv) Pelodictyon luteolum (Schmidle) comb. nov. Each of the two species of Chlorobium Nadson 1906 has an infrasubspecific forma specialis designated: Chlorobium limicola forma specialis thiosulfatophilum and Chlorobium vibrioforme forma specialis thiosulfatophilum. A revised description of each newly named organism is given. Neotype strains are designated.
\end{abstract}

The first comprehensive classification of the purple sulfur bacteria (Thiorhodaceae Molisch 1907, reference 9) was established by Winogradsky (19). It was based on careful microscopic observations of cell material which was collected in nature and kept for some time in crude cultures containing mud and water of the habitat. Differentiating criteria for the genera were the mode of development of cell aggregates, the structure of the aggregates, slime production, and the arrangement of the cells within the slime capsules (Bergey's Manual of Determinative Bacteriology, 7th ed.). During the past 10 years, most of the species described by Winogradsky have been isolated in pure culture and studied under varied experimental conditions (see 14). These studies revealed that the criteria used by Winogradsky are highly dependent on the growth conditions. Consequently, a classification of the Thiorhodaceae based on pure-culture studies has to rely primarily on the characteristics of the single cells. If the morphology of the cells is considered in the first place, most of Winogradsky's original genera and species can be maintained, though certain nomenclatural rearrangements become necessary. Therefore, we propose the following rearrangements, which are in agreement with the International Code of Nomenclature of Bacteria (2). Also, a few rearrangements were necessary with the green phototrophic bacteria.

Inclusion of Thiothece Winogradsky 1888 , in Thiocystis Winogradsky 1888. The genus Thiocystis Winogradsky 1888 , comprises the spherical, motile, gas-vacuole-free forms of the
Thiorhodaceae. Under unfavorable grow th conditions and in natural environments, cells may be immotile and grow in more-or-less regular aggregates surrounded by slime. In pure cultures under optimal growth conditions, the cells are freely motile and, except for their spherical shape, resemble those of the genus Chromatium Perty 1852.

The cells of the monotypic genus Thiothece Winogradsky 1888 are spherical (15). The specific epithet "gelatinosa," in the name of the single species Thiothece gelatinosa Winogradsky 1888 , refers to the formation of slime under natural conditions, which is equally characteristic for Thiocystis. In the type species Thiocystis violacea Winogradsky 1888 , the intracellular sulfur globules are distributed at random, whereas in Thiothece gelatinosa they are located at the inner periphery of the cells. In the genus Chromatium, all species except Chromatium warmingii (Cohn) Migula 1900 show random distribution of the sulfur globules in the cells. In $C$. warmingii, the globules of elemental sulfur are predominantly located at the two poles of the cells. In analogy to Chromatium, the different location of sulfur globules would not justify maintaining the monotypic genus Thiothece besides Thiocystis. The ultrastructure of representative strains of both genera is almost identical: the photosynthetic membrane system is of the vesicular type.

As a consequence of the reasons given above, we introduce the new combination:

Thiocystis gelatinosa (Winogradsky) Pfennig 
and Trüper (nov. comb.) (Synonyms: Thiothece gelatinosa Winogradsky 1888, Thiosphaera gelatinosa (Winogradsky) Miyoshi 1897, Lamprocystis gelatinosa (Winogradsky) Migula 1900, Chromatium sphaeroides Hama 1933).

ge.la.ti.no'sa. gelatus L. part. adj. frozen, stiffened; gelatinum M.L. n. gelatin, that which stiffens; gelatinosus M.L. adj. gelatinous.

Cells spherical, about $3 \mu \mathrm{m}$ in diameter; under unfavorable conditions, elongated ovoid cells may occur, due to delayed cell division. At high light intensity and sulfide concentration and under other unfavorable conditions, cells are immotile and grow in irregular aggregates surrounded by slime. Globules of elemental sulfur occur only in the peripheral part of the cytoplasm. Color of individual cells slightly pink; color of cell suspensions purple red.

Obligately phototrophic, strictly anaerobic. $p \mathrm{H}$ range 6.5 to 7.6 . Optimum growth temperature, 25 to $30 \mathrm{C}$. A salinity of $1 \% \mathrm{NaCl}$ is required by the neotype strain. Electron donors used in photosynthetic activity: sulfide, sulfur. In the presence of sulfide and bicarbonate, acetate and pyruvate are photoassimilated. Not utilized: thiosulfate, thioglycolate. Nitrogen sources: ammonium salts.

Pigments: bacteriochlorophyll $a$, carotenoids of the okenone series.

Storage materials: polysaccharides, poly- $\beta$ hydroxybutyrate, polyphosphates. Hydrogenase and catalase present.

Deoxyribonucleic acid (DNA) base ratio: 61.3 moles per cent guanine plus cytosine (buoyant density).

Habitat: stagnant water containing hydrogen sulfide and exposed to light; hypolimnion of meromictic lakes.

Illustrations: Winogradsky 1888 (reference 19, Plate III, Fig. 9-12); Pfennig et al. (15, Fig. $1)$.

Neotype strain: "Langvik" (SMG 215). The characteristics of the neotype strain are the same as those given above for the species, and they agree with those given by Winogradsky (19) in his original description of this organism.

Rearrangement of the genera Amoebobacter Winogradsky 1888, Rhodothece Molisch 1906, and Thiodictyon Winogradsky 1888 . In accordance with the original description of the type species of the genus Amoebobacter Winogradsky 1888, namely, Amoebobacter roseus Winogradsky 1888 , the genus should comprise only spherical, nonmotile, gas-vacuolecontaining species. Consequently, the species Amoebobacter bacillosus Winogradsky 1888, with rod-shaped cells very similar to those of
Thiodictyon elegans Winogradsky 1888, is transferred to the genus Thiodictyon Winogradsky 1888 :

Thiodictyon bacillosum (Winogradsky) Pfennig and Trüper (nov.comb.) (Synonyms: Amoebobacter bacillosus Winogradsky 1888; Rhodocapsa suspensa Molisch 1906.)

ba.cil.lo'sum. bacillus L. dim. n. a small rod; -osus L. suffix full of; bacillosus M.L. adj. full of, made up of small rods.

Cells 1.5 to $2.0 \mu \mathrm{m}$ wide, 3 to $6 \mu \mathrm{m}$ long. Cells may form irregular aggregates surrounded by slime. Net-like aggregates are not formed. Globules of elemental sulfur occur only in the peripheral cytoplasmic layer. Gas vacuoles are located in the central part of the cell. Color of individual cells, grayish; color of cell suspensions, purple violet.

Obligately phototrophic, strictly anaerobic. $p \mathrm{H}$ range 6.5 to 7.5 . Growth temperature 20 to $25 \mathrm{C}$. Electron donors used in photosynthetic activity: sulfide, sulfur. In the presence of sulfide and bicarbonate, acetate and pyruvate are photoassimilated. Incapable of assimilatory sulfate reduction. Nitrogen sources: ammonium salts.

Pigments: bacteriochlorophyll $a$, carotenoids of the rhodopinal series. Storage product: poly- $\beta$-hydroxybutyrate. DNA base ratio: 66.3 moles per cent guanine plus cytosine (buoyant density).

Habitat: mud and stagnant water containing hydrogen sulfide and exposed to light; sulfur springs.

Illustrations: Winogradsky 1888 (reference 19, Plate III, Fig. 7).

Neotype strain: "Zeulenroda" (SMG 234). The characteristics of the neotype strain are the same as those given above for the species, and they agree with those given by Winogradsky (19) in his original description of this organism.

The very slow movements of groups of cells and jerky movements of individual cells, described by Winogradsky (19) for Amoebobacter species, cannot be regarded as a generic characteristic. Such movements arise under certain conditions as artefacts of the microscopic observation technique and were observed by Pfennig (14) in all gas-vacuole-containing Thiorhodaceae (Lamprocystis, Thiodictyon, Thiopedia, and Amoebobacter).

The description of Rhodothece conspicua given by Skuja (17) is in agreement with the description of Amoebobacter roseus given by Winogradsky (19). Since there is no reason to maintain two genera for the spherical, nonmotile, gas-vacuole-containing species of the 
Thiorhodaceae, Rhodothece Molisch 1906 must be considered a later synonym of Amoebobacter Winogradsky 1888. Then Rhodothece conspicua Skuja becomes a later synonym of Amoebobacter roseus Winogradsky, the type species of the genus Amoebobacter; Rhodothece pendens Molisch 1906 becomes Amoebobacter pendens.

Amoebobacter pendens (Molisch) Pfennig and Trüper (nov. comb). (Synonyms: Rhodothece pendens Molisch 1906; Rhodothece nuda Skuja 1956.)

pen'dens. pendens L. part. adj. hanging.

Cells spherical, 1.5 to $2.5 \mu \mathrm{m}$ in diameter. Individual cells and irregular cell aggregates of different size surrounded by slime capsules. Depending on the culture conditions, slime formation can be very pronounced so that the culture becomes rather viscous. Contain gas vacuoles in the central part of the cell; globules of elemental sulfur occur only in the peripheral layer of the cytoplasm. Individual cells colorless, color of cell suspensions pink. Obligately phototrophic, strictly anaerobic. Vitamin $B_{12}$ required for growth. $p \mathrm{H}$ range 7.0 to 7.5 . Growth temperature 25 to $30 \mathrm{C}$.

Electron donors used in photosynthetic activity: sulfide, sulfur, thiosulfate, sulfite. In the presence of sulfide and bicarbonate, pyruvate and glucose are photoassimilated. Incapable of assimilatory sulfate reduction.

Not utilized: thioglycolate, acetate, other sugars, alcohols, sugar alcohols, higher fatty acids, amino acids, most intermediates of the tricarboxylic acid cycle.

Nitrogen sources: ammonium salts.

Pigments: bacteriochlorophyll $a$, carotenoids of the spirilloxanthin series. Hydrogenase and catalase present.

DNA base ratio: 65.3 moles \% guanine plus cytosine (buoyant density).

Habitat: mud and stagnant water containing hydrogen sulfide and exposed to light.

Illustrations: Molisch 1907, Plate II, fig. 13-14; Skuja 1956, Plate III, fig. 45.

Neotype strain: "Klein-Kalden" (SMG 236). The characteristics of the neotype strain are the same as those given above for the species, and they agree with those given by Molisch (1908) in his original description of this organism.

Illegitimacy of Pelodictyon aggregatum Perfiliev 1914. The name Pelodictyon aggregatum Perfiliev 1914 is illegitimate according to Rule 24b, International Code of Nomenclature of Bacteria (2). The correct name must be Pelodictyon luteolum based on the basionym
Aphanothece luteola Schmidle 1901. Consequently, we introduce the following new combination:

Pelodictyon luteolum (Schmidle) Pfennig and Trüper (nov. comb). (Synonyms: Aphanothece luteola Schmidle 1901; Schmidlea luteola (Schmidle) Lauterborn 1913; Pelodictyon aggregatum Perfiliev 1914.)

lu.te'o.lum. luteus L. adj. yellow; luteolus L. dim. adj. yellowish, little yellow.

Individual cells ovoid to short vibrio-shaped, 0.6 to $0.9 \mu \mathrm{m}$ wide by 1.2 to $2.0 \mu \mathrm{m}$ long, at times 1 to $1.5 \mu \mathrm{m}$ wide by 2 to $4 \mu \mathrm{m}$ long. In pure culture the organism may grow in the form of free individual cells; under certain conditions the cells produce slime and are united into hollow spherical or irregular round colonies with the cells in a single layer. The latter growth forms are occasionally observed in mud samples or enrichment cultures. Cells contain gas vacuoles. Color of cell suspensions green.

Obligately phototrophic, strictly anaerobic. $p \mathrm{H}$ range 6.5 to 7.0 .

Optimum growth temperature 20 to $25 \mathrm{C}$. Electron donors used in photosynthetic activity: sulfide, sulfur. In the presence of sulfide and bicarbonate, acetate and propionate are photoassimilated. Not utilized: thiosulfate, higher fatty acids, pyruvate, succinate, peptone. Incapable of assimilatory sulfate reduction. Nitrogen source: ammonium salts.

Predominant pigments: bacteriochlorophyll $c$ or $d$, and carotenoids. Hydrogenase may be present. DNA base ratios: 53.5 to 58.1 moles per cent guanine plus cytosine (buoyant density).

Habitat: mud and stagnant water containing hydrogen sulfide and exposed to light; sulfur springs.

Illustrations: Perfiliev (reference 12, Plate II, Fig 2); Lauterborn (reference 4, Plate III, Fig 29-31.)

Neotype strain: "Polden" (SMG 273). The characteristics of the neotype strain are the same as those given above for the species, and they agree with those given by Schmidle (16) in his original description of this organism.

Rearrangements in the genus Chlorobium Nadson 1906. The only difference between the type species of the type genus of Chlorobiaceae Copeland 1956 (18), namely Chlorobium limicola Nadson 1906, and Chlorobium thiosulfatophilum Larsen 1952 is the single physiological character of the latter to utilize thiosulfate in addition to the substrates utilized by both 
species. DNA base ratios, pigments, and fine structure do not indicate further distinct differences. On the other hand, within each of the two species there exist two morphological types, one of them has more or less straight rod-shaped cells, the other always has smaller vibrio-like curved cells with the tendency to form half circles, circles, and coils or spirals (14). A vibrio-shaped Chlorobium was named and described by Pelsh in 1936 (11), but has never been mentioned since: Chlorobium vibrioformis (sic) Pelsh 1936,63 (correctly: $C$. vibrioforme). Since there exist thiosulfateutilizing rod-shaped strains as well as vibrioid strains, the character to utilize thiosulfate should be expressed by an infrasubspecific differentiation within each of the two species Chlorobium limicola and Chlorobium vibrioforme.

Thus we introduce the terms Chlorobium limicola forma specialis thiosulfatophilum and Chlorobium vibrioforme forma specialis thiosulfatophilum for the thiosulfate-utilizing strains of the species Chlorobium limicola and Chlorobium vibrioforme, respectively. All neotype strains mentioned are deposited with the SMG (Sammlung für Mikroorganismen Göttingen), a newly established German microbial culture collection.

\section{LITERATURE CITED}

1. Hama, T. 1933. Nine species belonging to the order Thiobacteriales Buchanan, found in Hiroshima. J. Sci. Hiroshima Univ. Ser. B Div. 2 Bot. 1:157-163.

2. International Code of Nomenclature of Bacteria. 1966. Int. J. Syst. Bacteriol. 16:459-490.

3. Larsen, H. 1952. On the culture and general physiology of the green sulfur bacteria. $\mathbf{J}$. Bacteriol. 64:187-196.

4. Lauterborn, R. 1913. Zur Kenntnis einiger sapropelischer Schizomyceten. Allg. Bot. Z. 19:97-100.

5. Lauterborn, R. 1915. Die sapropelische Lebewelt. Ein Beitrag zur Biologie des Faulschlamms natürlisher Gewässer. Verh. Naturhist. Med. Ver. Heidelberg 13:395-481.
6. Migula, W. 1900. System der Bakterien, vol. 2. Gustav Fischer, Jena.

7. Miyoshi, M. 1897. Studien über die Schwefelrasenbildung und die Schwefelbacterien der Thermen von Yumoto bei Nikko. J. Colloid Sci. Imp. Univ. Tokyo 10(2):143-173.

8. Molisch, H. 1906. Zwei neue Purpurbakterien mit Schwebekörperchen. Bot. Ztg. Abt. 1 $54: 223-232$.

9. Molisch, H. 1907. Die Purpurbakterien nach neuen Untersuchungen. Gustav Fischer, Jena.

10. Nadson, G. A. 1906. The morphology of inferior algae III. Chlorobium limicola Nads., the green chlorophyll bearing microbe. (Russian). Bull. Jard. Bot. St. Pétersburg 6:190.

11. Pelsh, A. D. 1936. Hydrobiology of Karabugaz (Russian). Trud. Solyan. Lab. Akad. Nauk USSR, Moscow 5:49-80.

12. Perfiliev, B. V. 1914. The chlorophyll bearing microbe, Pelodictyon clathratiforme, of the green bacteria group, J. Mikrobiol. (Russian) 1:197.

13. Perty, M. 1852. Zur Kenntnis kleinster Lebensformen. Jent und Reinert, Bern.

14. Pfennig, N. 1967. Photosynthetic bacteria. Annu. Rev. Microbiol. 21:285-324.

15. Pfennig, N., M. C. Markham, and S. L. Jensen. 1968. Carotenoids of Thiorhodaceae. 8. Isolation and characterization of a Thiothece, Lamprocystis and Thiodictyon strain and their carotenoid pigments. Arch. Mikrobiol. 62:178-191.

16. Schmidle, W. 1901. Neue Algen aus dem Gebiete des Oberrheins. Beih. Bot. Zentralbl. 10: $179-180$.

17. Skuja, H. 1956. Taxonomische und biologische Studien über das Phytoplankton schwedischer Binnengewässer. Nova Acta Regiae Soc. Sci. Upsal. Ser. IV 16:(3): 1-404.

18. Trüper, H. G., and N. Pfennig. 1971. Family of phototrophic green sulfur bacteria: Chlorobiaceae Copeland, the correct family name; rejection of Chlorobacterium Lauteborn; and the taxonomic situation of the consortium-forming species. Request for an opinion. Int. J. Syst. Bacteriol. 21:8-10.

19. Winogradsky, S. 1888. Beiträge zur Morphologie und Physiologie der Bacterien. Heft 1. Zur Morphologie und Physiologie der Schwefelbacterien. Arthur Felix, Leipzig. 